\title{
A NOVEL VALIDATED HEADSPACE GAS CHROMATOGRAPHY METHOD FOR THE SIMULTANEOUS QUANTIFICATION OF THREE ORGANIC VOLATILE IMPURITIES IN ENROFLOXACIN PURE AND PHARMACEUTICAL DOSAGE FORMS
}

\author{
KRISHNA KISHORE J, PRASADA RAO K* \\ Department of Chemistry, ANU Research Centre, Bapatla Engineering College, Bapatla, Guntur, Andhra Pradesh, India. \\ Email: krishna4kishorephd@gmail.com
}

Received: 14 September 2020, Revised and Accepted: 13 October 2020

\begin{abstract}
Objective: This article describes a novel, simple, and rapid gas chromatographic method for quantification of three organic volatile impurities (OVIs) present in enrofloxacin and its pharmaceutical dosage forms.

Methods: ZB-624 $30 \mathrm{~m} \times 0.53 \mathrm{~mm}, 3.0 \mu$ column used as stationary phase and flame ionized detector is used as detector at $250^{\circ} \mathrm{C}$. The injector temperature is maintained at $180^{\circ} \mathrm{C}$. The nitrogen gas was used as a carrier gas with a flow rate of $4.0 \mathrm{~mL} / \mathrm{min}$. The method involved a thermal gradient elution. The total run time is $21.14 \mathrm{~min}$.

Results: The retention time of three OVIs taken individually and in spiked standard solutions were determined. The retention times are 2.30 min for methanol, $7.07 \mathrm{~min}$ for 1-butanol, and $8.48 \mathrm{~min}$ for toluene, respectively. The \% relative standard deviation for six injections should be not more than $10 \%$. The $\%$ recovery ranges from 85 to $115 \%$. The correlation coefficient $\left(\mathrm{r}^{2}\right)$ for linearity is not $<0.99$. The limit of quantification was found to be 260 ppm for methanol, 101 ppm for 1-butanol, and 56 ppm for toluene. Other validation parameters is done like as precision, ruggedness, robustness, solution stability, and Tablet analysis.
\end{abstract}

Conclusion: All the obtained results are found within the acceptable limits. The proposed method has been successfully applied for the quantification of OVIs present in enrofloxacin pure and its pharmaceutical dosage forms.

Keywords: Enrofloxacin, Organic volatile impurities, Method development, Validation.

(C) 2020 The Authors. Published by Innovare Academic Sciences Pvt Ltd. This is an open access article under the CC BY license (http://creativecommons. org/licenses/by/4. 0/) DOI: http://dx.doi.org/10.22159/ajpcr.2020.v13i11.39732

\section{INTRODUCTION}

Enrofloxacin (Fig. 1) is chemically known as 1-Cyclopropyl-7-(4-ethylpiperazin-1-yl)-6-fluoro-4-oxo-1,4-dihydro-quinoline-3-carboxylic acid. Chemical formula is $\mathrm{C}_{19} \mathrm{H}_{22} \mathrm{FN}_{3} \mathrm{O}_{3}$ and molecular weight is $359.4 \mathrm{~g} /$ mol. Enrofloxacin is often used in veterinary medicine to treat several bacterial diseases, as abscess, renal failure, carapace injury, oral cavity inflammation, cerebral meninges inflammation, gastrointestinal tract inflammation, lungs inflammation, wounds, abrasions, skin, and mucous membrane infection [1]. Hence, many solvents are used in the synthesis of enrofloxacin drug substances and in excipients used in the production of drug formulations. Many of these solvents generally cannot be completely removed by standard manufacturing processes preferably at low levels. These solvents like as organic volatile impurities (OVIs) are encounter during manufacture and storage of active pharmaceutical ingredients. The OVIs in the active pharmaceutical ingredients or from other drug manufacturing processes can be harmful for the human health [2]. The first problem that was facing the simultaneous quantification of these OVIs analysis of enrofloxacin in quality control was the inability of the present official methods.

The OVIs specifications were set in accordance with the toxicity of solvents vary from a low ppm to thousands of ppm. In general, OVIs are divided into three classes. Those are class-1, class-2, and class-3. Hence, in the synthetic process of enrofloxacin, methanol (class-3), 1-butanol (class-3), and toluene (class-2) are used as OVIs. After the drying process, analysis needs to be performed to check if amounts of solvents used at any step of the production do not exceed acceptable limits. The static gas chromatography headspace (GC-HS) quantification of OVIs is nowadays mature technique well established in pharmaceutical analysis [3]. Hence, our aim is to simultaneous quantification these three OVIs in a single method using GC-HS with flame ionized detector. The specifications of the three OVIs are $3000 \mathrm{ppm}$ for methanol, 1000 ppm for 1-butanol, and $500 \mathrm{ppm}$ for toluene. The structures of three OVIs are shown in Fig. 2.

In the literature review, few methods are reported on enrofloxacin. Some are stability indicating methods and combination method with other drug is available. Chakravarthy et al. reported as stabilityindicating reverse-phase high-performance liquid chromatography (HPLC) method for simultaneous estimation of enrofloxacin and its degradation products in tablet dosage forms [4]. Borges et al. reported as a simple and rapid HPLC method for the multi determination of enrofloxacin, ciprofloxacin, and oxytetracycline in raw materials and veterinary pharmaceutical formulations [5]. From these literature survey, there are no methods on quantification OVIs in enrofloxacin. Finally, we hope our method is novel and very sensitive technique. To the best of our knowledge, there are no reports on the validated simultaneous quantification of six OVIs in the enrofloxacin pure and pharmaceutical substances using GC-HS with flame ionized detector.

\section{METHODS}

Chemicals and reagents

Methanol, 1-butanol, toluene, and dimethyl sulfoxide were purchased from Sigma-Aldrich. Enrofloxacin pure drug was taken from a local well known research laboratory. Dimethyl sulfoxide is used as a diluent and blank.

Instrumentation and chromatographic conditions

Chromatography was performed on Shimadzu chromatographic system equipped with a Shimadzu GC-2010 system with FID, samples were 
injected through a Teledyne Tekmar HT3 ${ }^{\mathrm{TM}} \mathrm{HS}$. Data acquisition and integration were performed using GC solution software. The instrument parameters described below were set up to determine the OVIs.

\section{Chromatographic conditions}

Column: ZB-624 ( $30 \mathrm{~m}, 0.53 \mathrm{~mm}$ ID, $3 \mu \mathrm{m}$ ); carrier gas: Nitrogen; flow rate: $4.0 \mathrm{~mL} / \mathrm{min}$; injector temperature: $180^{\circ} \mathrm{C}$; split ratio: $1: 5$; oven program: Initial $60^{\circ} \mathrm{C}$ hold for $6 \mathrm{~min}$, increase the ramp rate $35^{\circ} \mathrm{C} / \mathrm{min}$ up to $240^{\circ} \mathrm{C}$, hold for $10 \mathrm{~min}$; detector temperature: $250^{\circ} \mathrm{C}$; air gas flow: $400 \mathrm{~mL} / \mathrm{min}$; hydrogen gas flow: $40 \mathrm{~mL} / \mathrm{min}$; total run time is $21.14 \mathrm{~min}$.

\section{HS sampler condition}

Vial condition temperature: $95^{\circ} \mathrm{C}$; needle temperature: $105^{\circ} \mathrm{C}$; transfer line temperature: $110^{\circ} \mathrm{C}$; vial conditioning time: $30 \mathrm{~min}$; vial pressurize time: $3.0 \mathrm{~min}$; inject time: $1.0 \mathrm{~min}$; injection volume: $1.0 \mathrm{~mL}$; GC cycle time: $45 \mathrm{~min}$.

\section{Preparation of standard solutions}

Specifications for OVI'S

Methanol is $3000 \mathrm{ppm}$, 1-butanol is $1000 \mathrm{ppm}$, and toluene is $500 \mathrm{ppm}$.

\section{Standard solution preparation}

Weighed and transferred about each $750 \mathrm{mg}$ of methanol, $250 \mathrm{mg}$ of 1-butanol, and $125 \mathrm{mg}$ of toluene into a $100 \mathrm{~mL}$ of the volumetric flask containing $70 \mathrm{~mL}$ of diluent and diluted to volume with diluent. Further taken $5.0 \mathrm{~mL}$ of the above solution into $50 \mathrm{~mL}$ of volumetric flask and diluted to volume with diluent.

The standard HS vials were prepared with $2 \mathrm{~mL}$ of the standard solution and seal the vial with aluminum closure. (The standard solution has been prepared with respect to enrofloxacin sample concentration).

Preparation of enrofloxacin sample solution $(250 \mathrm{mg} / \mathrm{mL})$ Accurately weighed about $500 \mathrm{mg}$ of enrofloxacin pure sample into a $10 \mathrm{~mL}$ headspace vial and add $2.0 \mathrm{~mL}$ of diluent and immediately sealed with aluminum closure.

\section{Preparation of enrofloxacin tablet solution}

Twenty tablets were weighed and powdered. An amount of powder equivalent to $500 \mathrm{mg}$ enrofloxacin was accurately weighed and transferred to a $\mathrm{HS}$ vial, add $2 \mathrm{~mL}$ of diluent and immediately sealed with aluminum closure.

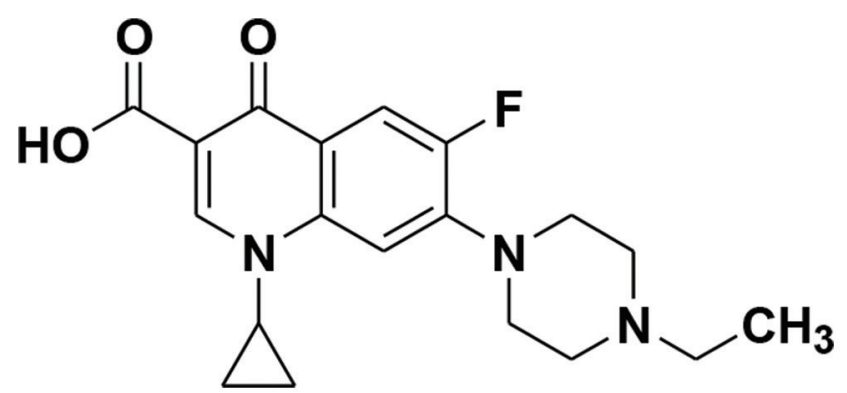

Fig. 1: Chemical structure of enrofloxacin

\section{Calculation}

The organic volatile impurity content was calculated from,

$$
\begin{aligned}
& \operatorname{PPM}(\mathrm{OVI})=\frac{\text { Impurity area in API }}{\text { Impurity area in standard solution }} \times \\
& \frac{\text { Standard solution concentration }}{\text { Sample solution concentration }} \times 10^{6}
\end{aligned}
$$

\section{GC-HS method development}

This method development was implemented following quality-bydesign principles including diluent selection and column selection. During the HS-GC method development, to select the most appropriate system parameters to obtain the best separation, sensitivity, and time efficiency, solvent mixtures were injected under a variety of conditions, for example, at different GC columns (DB-5, VF-1, ZB-624), HS temperatures, vial room temperature $\left(70-90^{\circ} \mathrm{C}\right)$, needle temperature $\left(80-110^{\circ} \mathrm{C}\right)$, transfer line temperature $\left(90-130^{\circ} \mathrm{C}\right)$, detector temperatures $\left(200-300^{\circ} \mathrm{C}\right)$, injector temperatures $\left(100-230^{\circ} \mathrm{C}\right)$, GC gradients $\left(40-230^{\circ} \mathrm{C}\right.$, at the rate of $\left.10-40^{\circ} \mathrm{C} / \mathrm{min}\right)$, carrier gas flow rates (2.0-4.0 $\mathrm{ml} / \mathrm{min})$, different diluents ( $\mathrm{N}$-Methyl-2-pyrrolidone, dimethyl sulfoxide, and dimethylformamide), etc. The final HS-GC conditions used for method validation were obtained based on optimized HS and GC parameters. Each of the solvents was injected once separately to determine method specificity and signal response sensitivity.

\section{RESULTS AND DISCUSSION}

\section{Method validation}

The method validation was done by evaluating specificity, repeatability, method precision, limit of detection (LOD) and limit of quantitation (LOQ), linearity, accuracy, ruggedness, and solution stability of residual solvents as indicated in the ICH harmonized tripartite guideline [2].

\section{Specificity}

Specificity of the method was shown by injecting the blank, sample preparation, and standard solution and showing the resolution between all peaks is in both sample solution and standard solution. The retention time of the three OVIs indicated that they were well separated from each other. The typical chromatograms of three OVIs and enrofloxacin are shown in Table 1 and Fig. 3.

\section{System precision}

System precision was determined by injecting six replicate injections of standard OVI solution, respectively, and analyzed as per ICH guidelines. The system precision of this method is expressed in the term of $\%$ relative standard deviation (RSD) of the data. The \% RSD was found to should be $<10 \%$. All values and chromatogram are shown in Table 2 and Fig. 4 .

\section{Method precision}

Method precision has been demonstrated by separately analyzing of standard OVIs six preparations as per the method. \%RSD was found to be $<10 \%$. All values and chromatograms are shown in Table 3 and Fig. 5 .

\section{Linearity for LOD and LOQ}

Linearity of the method was determined over the concentration range of $5-25 \%$ for four OVI'S. Two replicates were performed at each

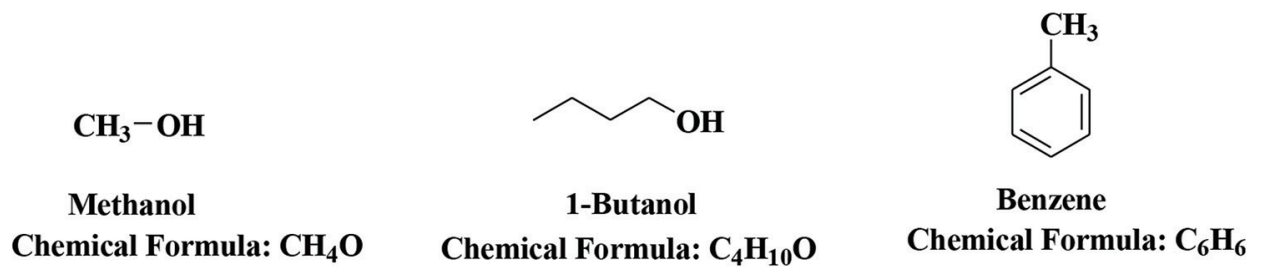

Fig. 2: Chemical structures of three organic volatile impurities 


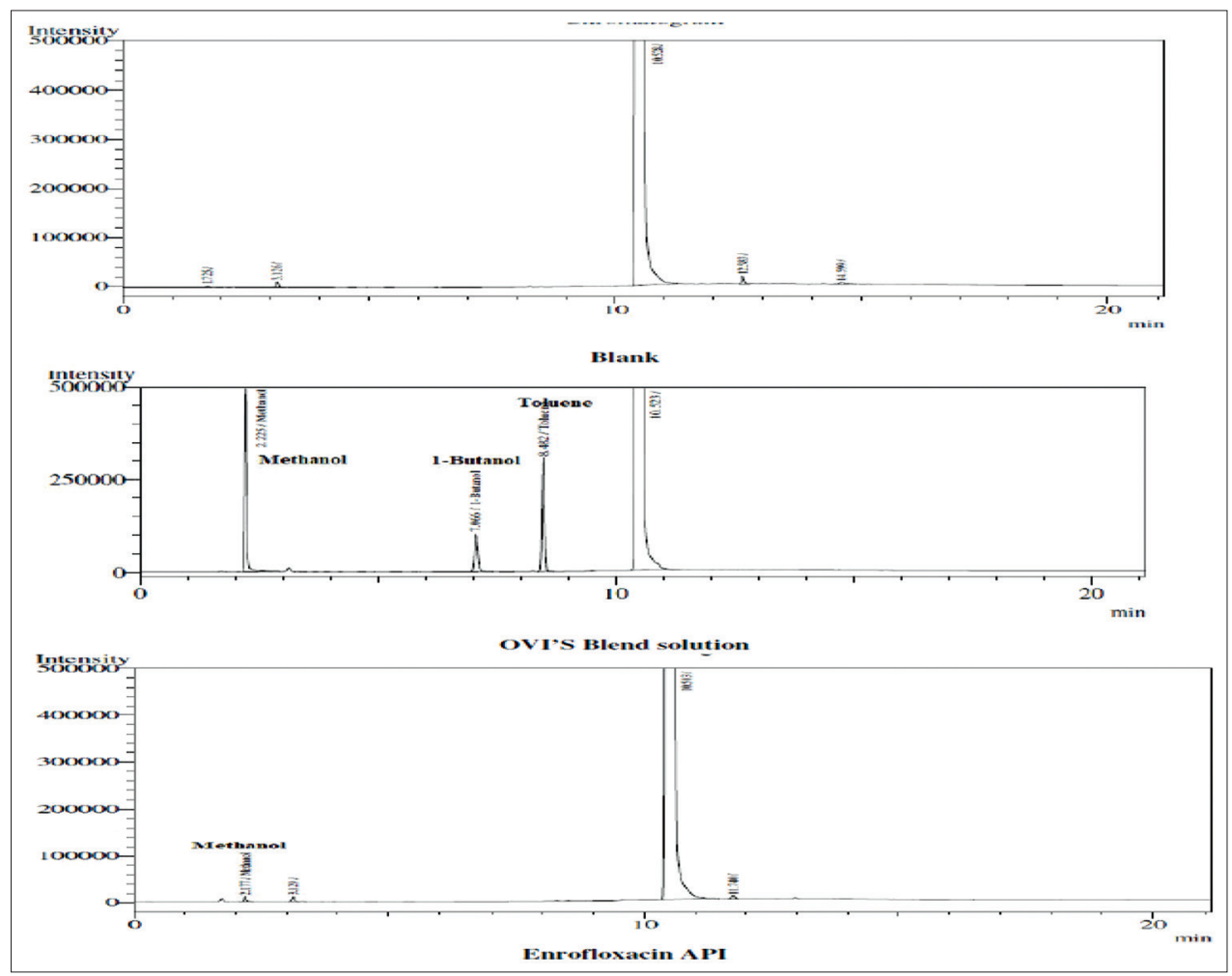

Fig. 3: Chromatograms for specificity

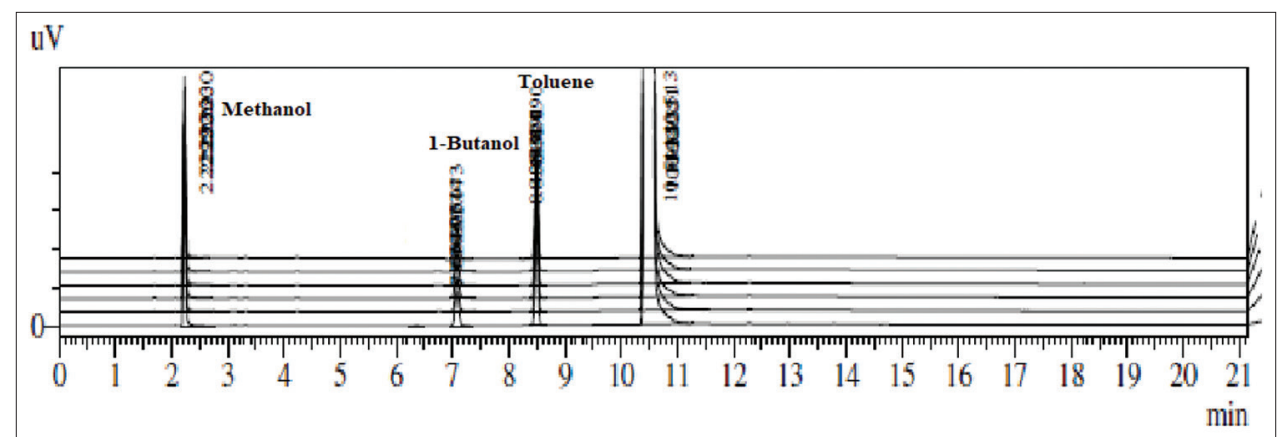

Fig. 4: Overlay chromatogram for system precision

Table 1: Specificity data for organic volatile impurities

\begin{tabular}{llllll}
\hline S. No. & Name of organic volatile impurities & RT & Theoretical plates & Tailing factor & USP resolution \\
\hline 1. & Methanol & 2.23 & 12976 & 1.25 & -- \\
2. & 1-Butanol & 7.07 & 49261 & 1.18 & 38.5 \\
3. & Toluene & 8.48 & 122966 & 1.05 & 11.25 \\
\hline
\end{tabular}

Table 2: System precision data for organic volatile impurities

\begin{tabular}{llll}
\hline No. of injections & Methanol & 1-Butanol & Toluene \\
\hline 1 & $1,378,901$ & 436,880 & $1,077,497$ \\
2 & $1,197,929$ & 399,464 & 996,593 \\
3 & $1,330,807$ & 424,521 & $1,084,919$ \\
4 & $1,343,481$ & 440,384 & $1,077,712$ \\
5 & $1,368,134$ & 432,735 & $1,099,049$ \\
6 & $1,256,913$ & 412,634 & $1,061,559$ \\
ACVG & $1,312,694$ & 424,436 & $1,066,222$ \\
STDV & 70,732 & 15,754 & 36,211 \\
\% relative standard deviation & 5.39 & 3.71 & 3.40 \\
\hline
\end{tabular}

level. Correlation coefficient $\left(\mathrm{R}^{2}\right)$, STEYX, SLOPE, LOD, and LOQ were calculated from these linearity data and shown in Table 4.

\section{LOD and LOQ}

The LOD and LOQ for the proposed method were determined using calibration standards and calculated using $3.3 \sigma / \mathrm{s}$ and $10 \sigma / \mathrm{s}$ formulae, respectively. The data and typical chromatograms are shown in Table 5 and Fig. 6.

\section{Linearity with LOQ}

The linearity of the method was determined by making injections of each organic volatile impurity over the range $25-150 \%$ and LOQ level. Two replicates were performed at each level. The calibration curves were obtained with the average of peak area ratios of two replicates. The correlation coefficient ( $\mathrm{r} 2$ ) values for all OVIs were found to be higher than 0.99 and the calibration curves were linear within the range. All values and linearity graph are shown in Table 6 and Fig. 7. 


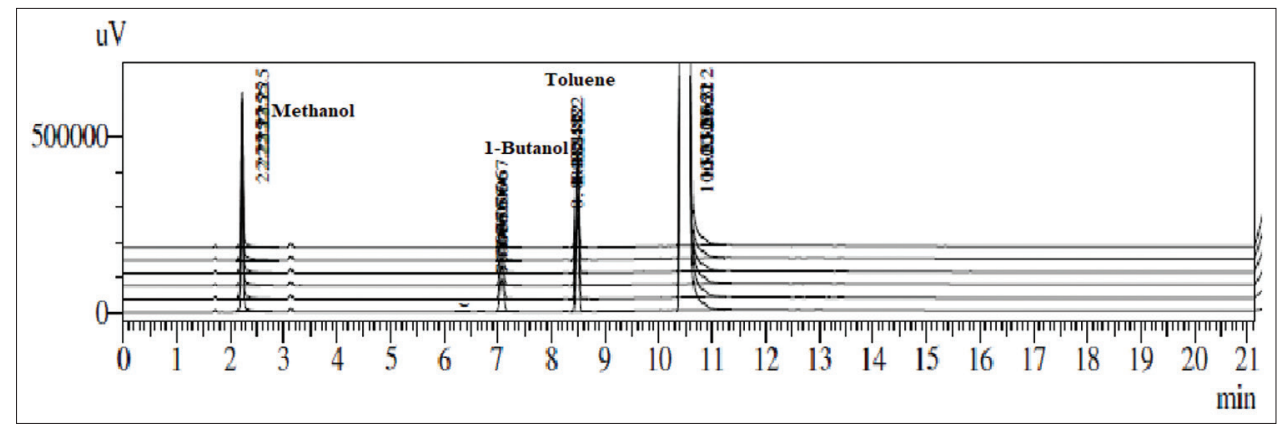

Fig. 5: Overlay chromatogram for method precision

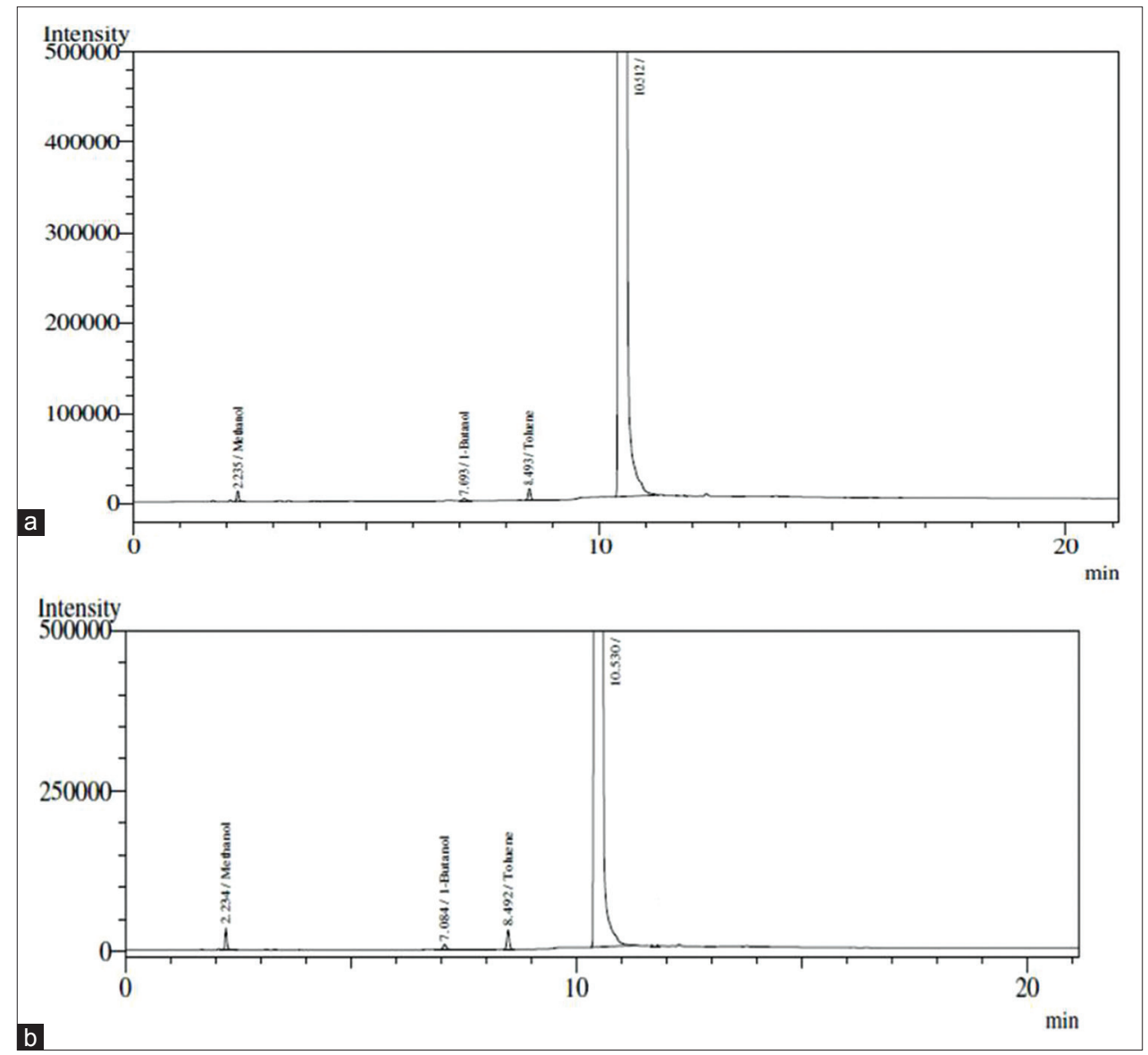

Fig. 6: (a) Limit of detection and (b) limit of quantitation chromatogram of three organic volatile impurities

Table 3: Method precision data for organic volatile impurities

\begin{tabular}{llll}
\hline No. of injections & Methanol & 1-Butanol & Toluene \\
\hline 1 & $1,389,126$ & 456,598 & 970,327 \\
2 & $1,418,852$ & 452,752 & $1,029,662$ \\
3 & $1,557,548$ & 436,063 & $1,070,474$ \\
4 & $1,337,642$ & 403,654 & 973,136 \\
5 & $1,553,607$ & 453,689 & $1,065,128$ \\
6 & $1,407,916$ & 454,787 & $1,008,756$ \\
ACVG & $1,444,115$ & 442,924 & $1,019,581$ \\
STDV & 90,735 & 20,637 & 43,512 \\
\% relative standard deviation & 6.28 & 4.66 & 4.27 \\
\hline
\end{tabular}

System precision at LOQ level

The system precision of this method is expressed in the term of \% RSD of the data. System precision at LOQ concentration has been demonstrated by six replicate injections of standard solutions. The $\%$ RSD was found out to be $<10 \%$ of each impurity. Results and overlay chromatogram are summarized in Table 7 and Fig. 8.

\section{Accuracy}

Accuracy of the methods was assured by applying the standard addition technique. The enrofloxacin pure sample is spiked with three different levels $(50 \%, 100 \%$, and $150 \%$ and LOQ) of OVIs. The \% recovery of each OVIs should be more than 85.0 and $<115.0$. Results obtained were within the limits indicating the method as accurate and are shown in Table 8.

\section{Robustness}

This study was performed by making small and deliberate variations in the method parameters. The variation in the column flow $( \pm 0.2 \mathrm{~mL} /$ $\min )$ and vial condition temperature $\left( \pm 5^{\circ} \mathrm{C}\right)$ was done and the results 


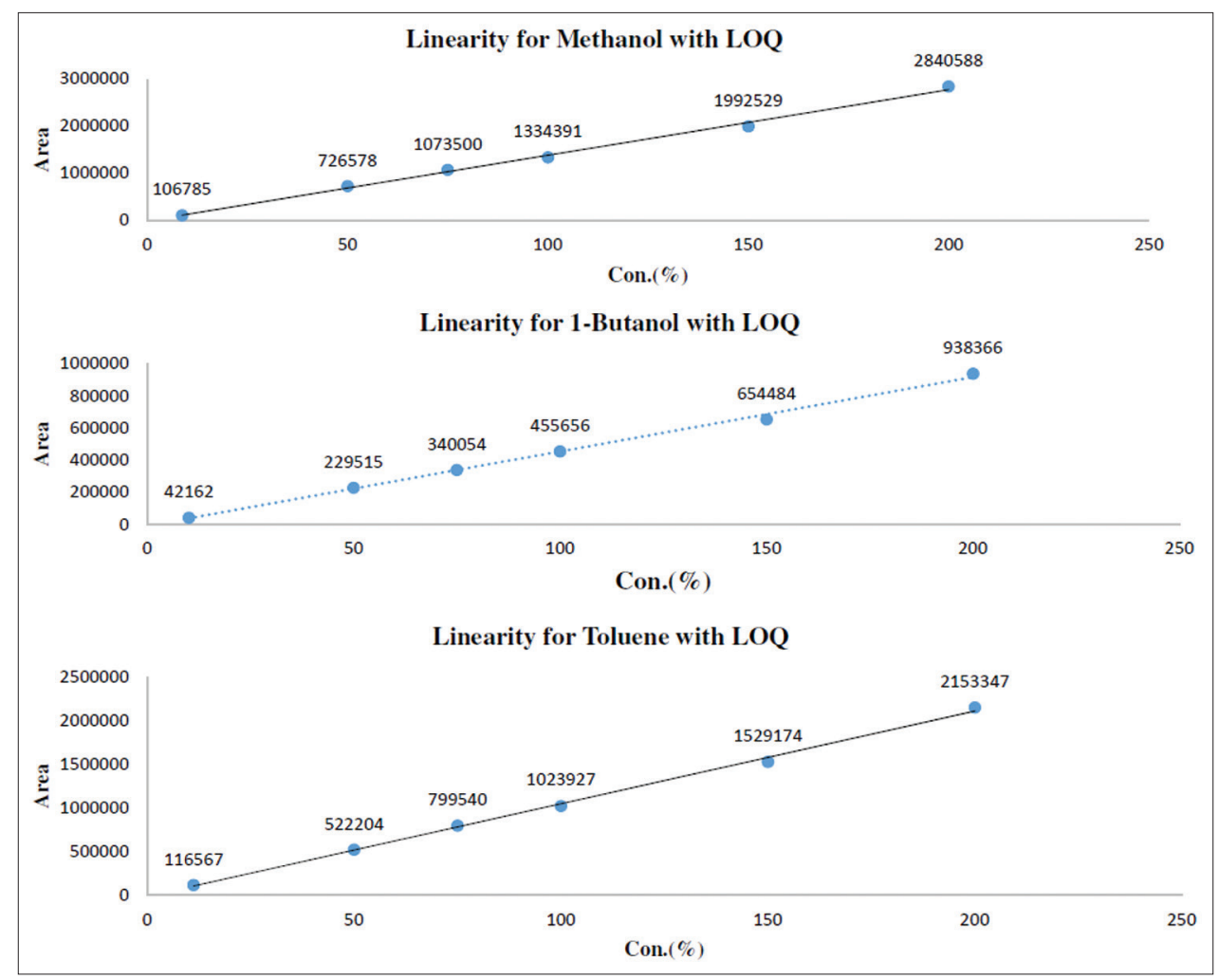

Fig. 7: Correlation graphs for three organic volatile impurities

Table 4: Linearity (low level) data for LOD and LOQ

\begin{tabular}{|c|c|c|c|}
\hline \multirow[t]{2}{*}{ Con. (\%) } & Methanol & 1-Butanol & Toluene \\
\hline & Avg. area $(n=2)$ & Avg. area $(n=2)$ & Avg. area $(n=2)$ \\
\hline 5 & 84,011 & 21,676 & 74,485 \\
\hline 10 & 136,735 & 37,410 & 97,244 \\
\hline 15 & 232,120 & 63,366 & 157,109 \\
\hline 20 & 290,334 & 83,428 & 211,139 \\
\hline 25 & 348,871 & 95,814 & 254,035 \\
\hline r2 & 0.996 & 0.994 & 0.993 \\
\hline STEYX & 11,867 & 3928 & 10,609 \\
\hline SLOPE & 13,666 & 3886 & 9460 \\
\hline LOQ (\%) & 8.68 & 10.11 & 11.21 \\
\hline LOD (\%) & 2.87 & 3.34 & 3.70 \\
\hline
\end{tabular}

LOD: Limit of detection, LOQ: Limit of quantitation

Table 5: LOD and LOQ data for three organic volatile impurities

\begin{tabular}{lllll}
\hline OVIs & $\begin{array}{l}\text { LOD Con. } \\
\text { (ppm) }\end{array}$ & $\begin{array}{l}\text { LOQ Con. } \\
(\mathbf{p p m})\end{array}$ & LOD area & LOQ area \\
\hline Methanol & 86 & 260 & 34230 & 106785 \\
1-Butanol & 33 & 101 & 12460 & 42162 \\
Toluene & 19 & 56 & 48462 & 116567 \\
\hline
\end{tabular}

LOD: Limit of detection, LOQ: Limit of quantitation, OVIs: Organic volatile impurities

were obtained within the acceptance criteria, indicating that the method is robust within the specified range. \% RSD values were $<10 \%$, as shown in Table 9.

\section{Ruggedness}

Ruggedness of the method was evaluated by performing the sample analysis in six replicates using different analyst on different days and
Table 6: Linearity data for organic volatile impurities

\begin{tabular}{|c|c|c|c|}
\hline \multirow[t]{2}{*}{ Con.(\%) } & Methanol & 1-Butanol & Toluene \\
\hline & Avg. area $(n=2)$ & Avg. area $(n=2)$ & Avg. area $(n=2)$ \\
\hline LOQ Con. & 106,785 & 42,162 & 116,567 \\
\hline 50 & 726,578 & 229,515 & 522,204 \\
\hline 75 & $1,073,500$ & 340,054 & 799,540 \\
\hline 100 & $1,334,391$ & 455,656 & $1,023,927$ \\
\hline 125 & $1,992,529$ & 654,484 & $1,529,174$ \\
\hline 150 & $2,840,588$ & 938,366 & $2,153,347$ \\
\hline r2 & 0.998 & 0.999 & 0.999 \\
\hline
\end{tabular}

Table 7: System precision data at limit of quantitation

\begin{tabular}{llll}
\hline No. of injections & $\begin{array}{l}\text { Methanol } \\
\text { area }\end{array}$ & $\begin{array}{l}\text { 1-Butanol } \\
\text { area }\end{array}$ & $\begin{array}{l}\text { Toluene } \\
\text { area }\end{array}$ \\
\hline Run-1 & 103,352 & 38,842 & 113,023 \\
Run-2 & 104,946 & 43,389 & 114,391 \\
Run-3 & 106,537 & 44,340 & 116,826 \\
Run-4 & 106,633 & 40,660 & 117,875 \\
Run-5 & 107,479 & 42,307 & 117,107 \\
Run-6 & 111,762 & 43,435 & 120,178 \\
ACVG & 106,785 & 42,162 & 116,567 \\
STDV & 2846 & 2058 & 2546 \\
\% relative standard deviation & 2.67 & 4.88 & 2.18 \\
\hline
\end{tabular}

the results were obtained within the acceptance criteria, indicating that the method is rugged within the specified range. The \% RSD is obtained not more than $10 \%$. The results are presented in Table 10.

Enrofloxacin pharmaceutical application

The proposed method was evaluated by the assay of commercially available enrofloxacin tablet for quantification of OVIs present in it. 


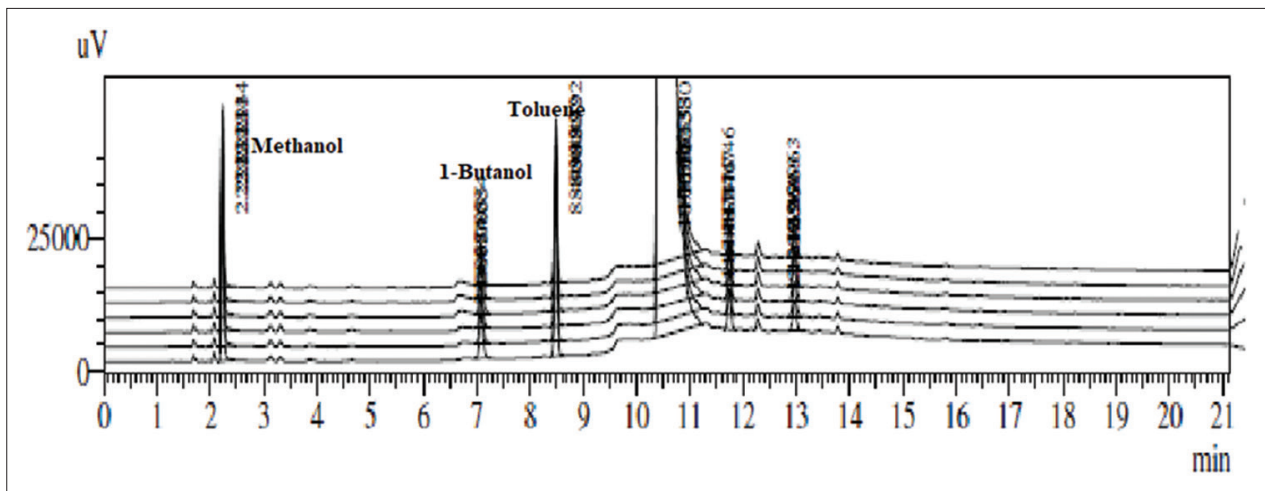

Fig. 8: Overlay chromatogram for limit of quantitation precision

Table 8: Accuracy data for OVIs

\begin{tabular}{|c|c|c|c|c|c|c|c|}
\hline OVI'S & $\begin{array}{l}\text { Avg. sample } \\
\text { area }(n=3)\end{array}$ & $\begin{array}{l}\text { Avg. STD area } \\
(n=6)\end{array}$ & $\begin{array}{l}\text { Avg. } 50 \% \text { area } \\
(n=3)\end{array}$ & $\begin{array}{l}\text { Avg. } 100 \% \text { area } \\
(n=3)\end{array}$ & $\begin{array}{l}\text { Avg. } 150 \% \text { area } \\
(n=3)\end{array}$ & \multicolumn{2}{|c|}{$\%$ recovery } \\
\hline \multirow[t]{3}{*}{ Methanol } & 28,597 & $1,312,694$ & 695,859 & $1,421,799$ & $2,027,423$ & 50 & 101.66 \\
\hline & & & & & & 100 & 106.13 \\
\hline & & & & & & 150 & 101.51 \\
\hline \multirow[t]{3}{*}{ 1-Butanol } & Not detected & 424,436 & 199,414 & 448,800 & 639,257 & 50 & 93.97 \\
\hline & & & & & & 100 & 105.74 \\
\hline & & & & & & 150 & 100.41 \\
\hline \multirow[t]{3}{*}{ Toluene } & Not detected & $1,066,222$ & 480,364 & $1,000,517$ & $1,485,189$ & 50 & 90.11 \\
\hline & & & & & & 100 & 93.84 \\
\hline & & & & & & 150 & 92.86 \\
\hline
\end{tabular}

OVIs: Organic volatile impurities

Table 9: Robustness data for three OVIs

\begin{tabular}{|c|c|c|c|c|}
\hline \multirow{2}{*}{$\begin{array}{l}\text { Name of } \\
\text { OVIs }\end{array}$} & \multicolumn{2}{|c|}{ Flow rate $(\mathrm{mL} / \mathrm{min})$} & \multicolumn{2}{|c|}{ Vial cond. temperature $\left({ }^{\circ} \mathrm{C}\right)$} \\
\hline & $\begin{array}{l}3.8 \mathrm{~mL} / \mathrm{min} \\
(\% \mathrm{RSD})\end{array}$ & $\begin{array}{l}4.2 \mathrm{~mL} / \mathrm{min} \\
(\% \mathrm{RSD})\end{array}$ & $\begin{array}{l}90^{\circ} \mathrm{C} \\
(\% \mathrm{RSD})\end{array}$ & $\begin{array}{l}100^{\circ} \mathrm{C} \\
\text { (\%RSD) }\end{array}$ \\
\hline Methanol & 6.44 & 6.92 & 3.40 & 7.84 \\
\hline 1-Butanol & 3.10 & 3.22 & 5.25 & 5.32 \\
\hline Toluene & 5.40 & 7.60 & 1.76 & 6.39 \\
\hline
\end{tabular}

OVIs: Organic volatile impurities, RSD: Relative standard deviation

Table 10: Ruggedness data for four organic volatile impurities

\begin{tabular}{|c|c|c|c|}
\hline Different days and analysts & $\begin{array}{l}\% \text { RSD for } \\
\text { methanol }\end{array}$ & $\begin{array}{l}\% \text { RSD for } \\
\text { 1-butanol }\end{array}$ & $\begin{array}{l}\text { \%RSD for } \\
\text { toluene }\end{array}$ \\
\hline \multicolumn{4}{|l|}{ Day-1 } \\
\hline Analyst-1 (n=6) & 7.15 & 7.56 & 4.20 \\
\hline Analyst $-2(n=6)$ & 2.93 & 3.23 & 1.64 \\
\hline Analyst- 1 and2 $(n=12)$ & 5.35 & 5.61 & 3.07 \\
\hline \multicolumn{4}{|l|}{ Day-2 } \\
\hline Analyst-1 $(n=6)$ & 8.39 & 8.16 & 4.12 \\
\hline Analyst- $2(n=6)$ & 4.59 & 5.26 & 4.01 \\
\hline Analyst- 1 and $2(n=12)$ & 7.17 & 6.74 & 3.88 \\
\hline \multicolumn{4}{|l|}{ Analyst-1 } \\
\hline Day-1 and $2(n=12)$ & 7.83 & 7.73 & 4.09 \\
\hline \multicolumn{4}{|l|}{ Analyst-2 } \\
\hline Day-1 and $2(n=12)$ & 3.72 & 4.21 & 3.14 \\
\hline
\end{tabular}

RSD: Relative standard deviation

The results obtained for OVIs were compared with the corresponding specification limits of standard guidelines and reported in Table 11. This revealed that OVIs present in enrofloxacin tablet at ppm levels which were less than the specified limits.
Table 11: Three organic volatile impurities content in tablet analysis

\begin{tabular}{lllll}
\hline Name of drug & $\begin{array}{l}\text { Label claim } \\
\text { (mg) }\end{array}$ & $\begin{array}{l}\text { Methanol } \\
\text { (ppm) }\end{array}$ & $\begin{array}{l}\text { 1-Butanol } \\
\text { (ppm) }\end{array}$ & $\begin{array}{l}\text { Toluene } \\
\text { (ppm) }\end{array}$ \\
\hline $\begin{array}{l}\text { Enrofloxacin } \\
\text { (Enroquin }^{\mathrm{TM}} \text { ) }\end{array}$ & $68 \mathrm{mg}$ & 601 & Not detected & $\begin{array}{l}\text { Not } \\
\text { detected }\end{array}$ \\
\hline
\end{tabular}

\section{CONCLUSION}

Finally, from the above all method validation data, we have to concluded, this is the novel GC-HS method for the simultaneous quantification of six OVIs in enrofloxacin API. Methanol, 1-butanol, and toluene were well separated from each other and quantified by the proposed method. The good results are obtained in each validation parameter as per ICH guidelines. We reported that the LOD and LOQ value was very low level from this method. We have to prove this GC-HS method is also suitable for the quantification of OVIs in pharmaceutical dosage forms. The proposed method was validated as per the ICH guidelines and the results revealed that the method was scientifically. This investigation may be helpful to the manufacturers for controlling and minimization of the OVIs. Moreover, this method was found to be applicable for the routine analysis of the enrofloxacin API in the pharmaceutical industry.

\section{AUTHORS' CONTRIBUTIONS}

Dr. K. Prasada Rao supervised the manuscript preparation and reviewed manuscript. I would like to thank the whole staff of the Chemistry Department of Bapatla Engineering College for their technical support and productive discussions.

\section{CONFLICTS OF INTEREST}

The authors declare that they have no conflicts of interest. 


\section{AUTHORS' FUNDING}

I would like to thank the Chemistry Department of Bapatla Engineering College for their financial support.

\section{REFERENCES}

1. Salvi JP, Salvi JP, Kirilov P, Perrot S, Pignon C. Development of a HPLC method for the determination of enrofloxacin and ciprofloxacin in reptile plasma after transdermal delivery. Int J Pharm 2015;5:571-6.

2. ICH Harmonized Tripartite Guidelines for Residual Solvents; 1997.
3. Fliszar K, Wiggins JM, Pignoli CM, Martin GP, Li Z. Analysis of organic volatile impurities in pharmaceutical excipients by static headspace capillary gas chromatography. J Chromatogr A 2004;1027:83-91.

4. Chakravarthy VA, Sailaja BB, Kumar AP. Stability-indicating RPHPLC method for simultaneous estimation of enrofloxacin and its degradation products in tablet dosage forms. J Anal Methods Chem 2015;2015:735145.

5. Borges MM, Moraes CT, Borges W, Borges KB. A simple and rapid HPLC method for the multi determination of enrofloxacin, ciprofloxacin, and oxytetracyclin in raw materials and veterinary pharmaceutical formulations. Curr Pharm Anal 2018;14:397-404. 